\title{
PHYTO REMEDIATION OF WASTE WATER THROUGH AQUATIC PLANTS FOR THE CHANGE DETECTION ANALYSIS IN THE CHEMICAL PROPERTIES WITHIN THE DISTRICT DHANBAD, JHARKHAND
}

\author{
Pawan Kumar Gupta ${ }^{1}$, Kumar Nikhil ${ }^{2}$, Kumar Mayank ${ }^{3}$ \\ ${ }^{1}$ Student of B.E (Biotecnology) IIIrd year, R.V College of Engineering, Bangalore, Karnataka, India \\ ${ }^{2}$ Principal Scientist, EMG, CSIR-CIMFR, Barwa Road, Dhanbad-826015, Jharkhand, India \\ ${ }^{3}$ Student of B.E (Biotecnology) IIIrd year, R.V College of Engineering,. Bangalore, Karnataka, India
}

\begin{abstract}
The paper briefly describes the importance of algae, vetiver grass, hydrilla and water hyacinth (Aquatic plant) in the phytoremediation of coal mine and municipal wastewater bio-purifications. A laboratory scale experiment was conducted by taking two mines, one municipal wastewater and which was compared with tap water treated by algae, vetiver grass, hydrilla and water hyacinth. The water samples were collected from mines from Jharia, Dhanbad. Municipal waste water was taken from Bekar Bandh, Dhanbad and were compared with the tap water from C.I.M.F.R, Barwa Road, Dhanbad of Jharkhand. Utilization of aquatic plant for bio-treatment of wastewater was a common practice all over the world. Use of Algae, Vetiver grass, Hydrilla and Waterhyacinth for the treatment of different types of wastewater were being practiced by researchers. But treating mine water by these aquatic plants were not in common. With the view mine water, municipal waste water and tap water were compared by the different combination of algae, vetiver grass, hydrilla and water hyacinth for the reduction or increases in the chemical properties studied e.g., pH, Sulphate, nitrate, and iron content of the water.
\end{abstract}

Experiment proved that the significant reduction in $\mathrm{pH}$, Nitrate, Sulphate, Iron with Algae, Vetiver grass, Hydrilla and Water hyacinth in all the water samples taken for this study. This type of experiment will have more scope by conducting it at the bigger scale to get accurate results.

Keywords: Phytoremediation 1, Mine Water 2, Municipal Waste Water 3, Algae 4, Vetiver grass( Vetiveria zizanioides) 5, Hydrilla (Hydrilla verticilita) 6, Water hyacinth [Eichhornia crassipes (Marri, Solms)] 7, and,Tap Water 8, Treatments9.

\section{INTRODUCTION}

Wastewater treatment is the process of taking wastewater and making it suitable for discharging back into the environment. It is an important initiative which has to be taken more seriously for the betterment of the society and our future. The wastewater treatment methods are of three types i.e. physical, chemical and biological.

Physical treatment is very common method where sedimentation, coarse screening, aeration and filtration is done to remove the physically from wastewater. The most common method to treat water using chemicals is chlorination, ozonation and neutralization. The best example is the use of carbon, which adsorbs contaminants to clean the water. Similarly, in biological treatment process, microorganisms such as bacteria are used to biochemically decompose the wastewater and stabilize the end product. This method is further divided into aerobic and anaerobic system. Use of aquatic floating plant to treat wastewater is also categorized in this method (Araki, et.al., 2003;
Archibald, 1972; Awuah, et.al., 2004; Wolverton \& McDonald, 1981; Borges, et.al., 2008; Braarud, T, 1945; Butcher, R.W, 1949; Chao, et.al., 2000; Mkandawire and Dudel, 2010; Mulbry, et.al.,2008; Piyush, et.al., 2012; Saravanan, et.al., 2013; Sarijeva, et.al., 2007; Ting, et.al.,1989; Tredici, 2010; Tseng, 2000).

It takes up large amounts of inorganic nutrients (especially Nitrate, Sulphate, Phosphate, etc., (Reddy, 1983)) and heavy metals (such as $\mathrm{Cd}, \mathrm{Cu}, \mathrm{Hg}, \mathrm{Fe}, \mathrm{Zn}$, etc.,) as a consequence of the growth requirements (Nakajima, et.al., 1981; Prasad, Prasad, 1995' Sakaguchi. et.al., 1981; Skinner, et.al., 2007; Soeder, 1981; Tukendorf, 1993; Vesk, et.al., 1999; Vesk, et.al., 1999) and decrease the concentration and ultimately lowering down the $\mathrm{pH}$, EC, etc., (Cornwell, et.al., 1977; Craggs, et.al., 1996; Dr.Konstantian bloch, 2001; Dhir, et.al., 2008; Droste, R.L, 1997; Filip, et.al., 1979; Fritioff and Greger 2006; Alade \& Ojoawo, 2009; Ghanshyam and Nikhil, 2014; Girija, et.al., 2011; Mazen and Maghraby, 1998) 
This paper investigated the effectiveness of the four floating aquatic plants such as Eichhornia crassipes (Marri, Solms) (Gopal, B, 1987; Reddy and Tucker, 1983; Mahmood, et.al., 2005; Paiva, et.al., 2009and Wooten \& Dodd, 1976), Vetiveria zizanioides (Ralph and Paul,2004; Roongtanakiat, 2004), Hydrilla verticilita (Kanabkaew, and Puetpaiboon, 2004; Pal,et.al., 2005; Pal, et.al., 2004; Vasquez, 2008) and Algal spp. e.g Spirogyra, Diatom, Volvox, Oscillatoria, Cynobacterium, Clausterium and Euglen all together in a combination treated all four type of water performed the experiment in the laboratory (Grobbelaar, 1990; Hammouda, et.al., 1994; Hassette, et.al., 1981; Mata, et.al., 2010; Palmer, 1969) i.e. two mine and one municipal wastewater treatment compared with one tap water. The role of these plants in removing nutrients e.g., Nitrogen as nitrate, Sulphur as sulphate, heavy metals like Fe and water $\mathrm{pH}$ was noticed in the four different set of aquatic floating plant system treated the four different water sample in this experiment (Kumar Nikhil, 2004; Kumar and Chopra, 2012; Laliberte, et.al., 1994; Lovaie, et.al., 1985; Mackenthum, 1962; Oswald and Gootas, 1957and Oswald, 1988).

\section{EXPERIMENTAL LAYOUT}

The experiment was conducted and planned for two coal mine and one municipal wastewater with one tap water treated with algae, vetiver grass, hydrilla and water hyacinth and by growing these floating aquatic plants in the tub at laboratory scale experiment in CSIR-CIMFR, Dhanbad, Jharkhand. The experiment was conducts to study the reduction in some of the chemical properties of mine and municipal wastewater compared with one tap water, with an interval of 0 day, 5day, 10 days, 15 days. Purification of coal mine and municipal waste water with tap water were studied and measured the most significant chemical parameters which were highly reduced by these aquatic plants in all sample collected. For achieving the same objective, this experiment was designed.

\subsection{Site Details}

This study was planned within Jharia Coalfield Area as this is very old coalfield of our country which is highly polluted in the world ranking. Huge opencast coalmining exist in this coalfield and huge amount of waste/mine water is locked within these coal opencast pits within the mining areas unused. With the utilities benefits of this huge waste/mine water for many fold purposes this study was planned which is very smallest approach but for setting a milestone for others experiment was at bigger scale this was carried out.

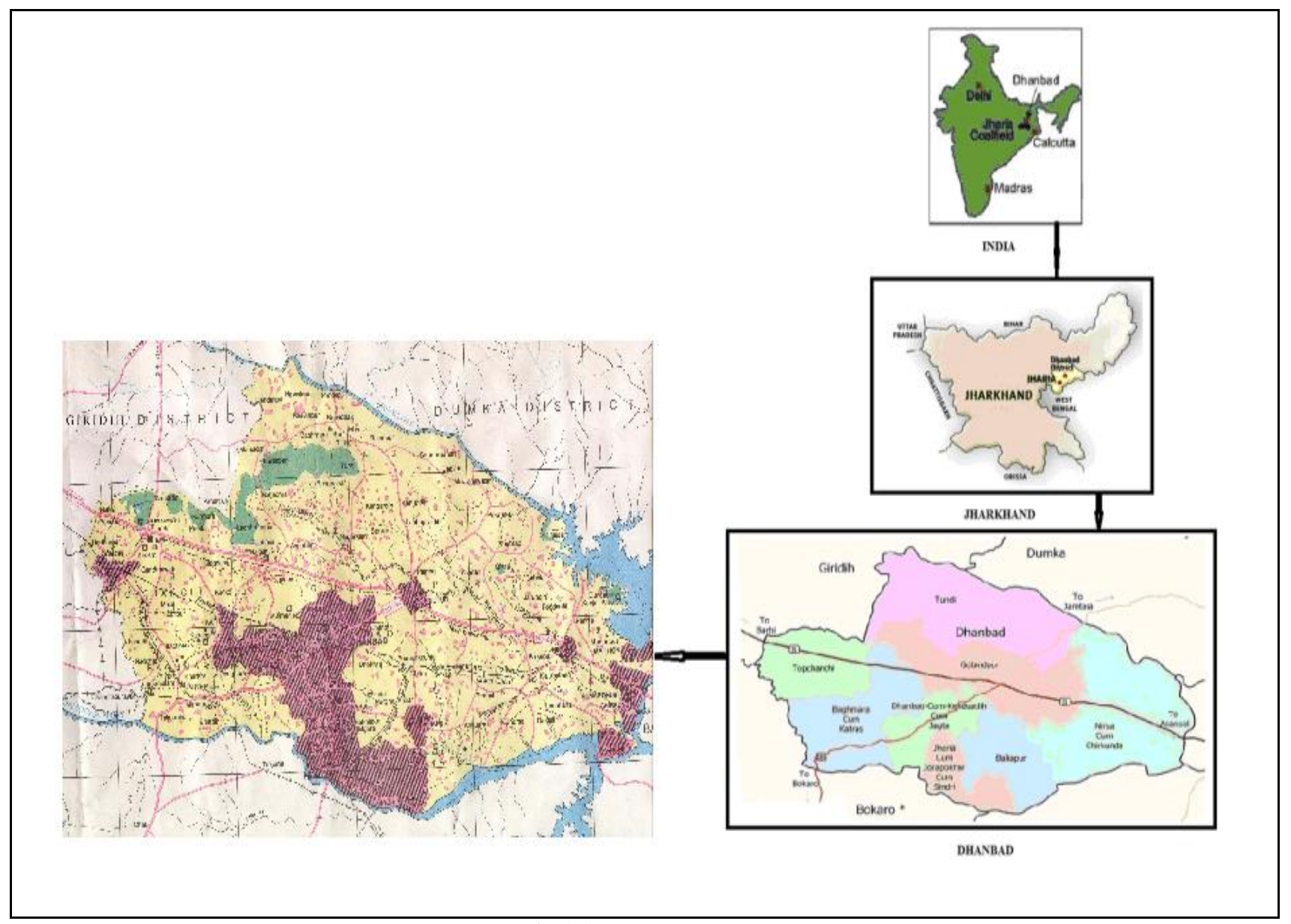

Fig.2.1: Detail site Map 


\subsection{Sampling Area}

Golden pahadi and 36 no. mining area in Jharia Coalfield (JCF) mine area water samples were taken. Along with BekarBandh municipal wastewater and CIMFR tap water were taken for this experiment. These all are situated in district of Dhanbad.

\subsection{Geogrophical Location of Experimental Site}

Golden pahadi and 36 no. mining area in JCF two mine waste water sample were collected at the geographical coordinates $23.72^{\circ} \mathrm{N} 86.40^{\circ} \mathrm{E}$ and $23.751568^{\circ} \mathrm{N} 86.420345^{\circ} \mathrm{E}$ respectively. Whereas Bekarbandh pond is situated in longitudes E $86^{\circ} 25^{\prime} 45.12^{\prime}$ 'and latitudes N 23 $48^{\prime} 2.16^{\prime}$ and CSIR-CIMFR ,Barwa Road, Dhanbad is situated in between

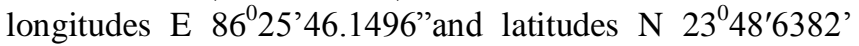
respectively (Fig.2.1).

\subsection{Material and Lab Instrument}

1. All required glassware

2. All required chemical and reagent

3. Electronic Balance

4. $\mathrm{pH}$ meter ( $\mathrm{pH}$ meter)

5. Filter paper

6. Conductivity meter (EC-meter)

7. Nitrate, Sulphate \& Iron test (Spectrophotometer)

8. Water measuring beaker

9. Required Tub of 10 liters water capacity

10. Algae

11. Water hyacinth

12. Vetiver grass

13. Hydrilla

\subsection{Methodology}

Local algal species in combination were identified by the help of microscope and water hyacinth (Eichhorniacrassipes) is a perennial, freshwater aquatic vascular plant with rounded, upright, shiny green leaves and spikes of lavender flowers were live plants brought for conducting the experiment. The petioles of the plant are spongy with many air spaces and contribute to the buoyancyof the hyacinth plant. When grown in wastewater, individual plants range from 0.5 to1.2 $\mathrm{m}$ (20 to $47 \mathrm{in}$.) from the top of the flower to the root tips. The plants spreadlaterally until the water surface is covered and then the vertical growth increases. Waterhyacinths are very productive photosynthetic plants.

Algal, Vetiver grass, Hydrilla and Water hyacinth samples are collected for the study and purification of coal mine and municipal waste water. These algal, Vetiver grass, Hydrilla and Water hyacinth floating aquatic plants samples are collected from Bekarbandh pond in district of Dhanbad.

To study the biopurification of coal mine and municipal wastewater, the following experiment design employed were shown in the Table. 2.1.

(i) MW1= Golden pahadi Mine Water, Bwhora (ii) MW2= Jharia Mine no.36 Mine Water

(iii) $\mathrm{BBW}=$ BekarBandh pond Water

(iv) $\mathrm{TW}=$ Tap Water

One hundred sixty (160) small tubs were brought with a capacity of 10 liters water. All tubs were arranged in sixteen rows (treatments) with the ten replications in each treatment. In the first set, first-four row tubs (treatment) were filled with 10 lit of Golden pahadi mine waste water (1) treated with algae, water hyacinth, vetiver grass and hydrilla. Whereas in the second set 36 no. mining area in Jharia Coalfield from fifth-eighth rows contain mine waste water (2) treated with these four aquatic plants. Further, in the ninth to twelfth rows the municipal waste water from Bekarbandh were treated with these four aquatic plants. Again from thirteen row to sixteen rows the tap water which were treated with these four aquatic plants (Table.2.1) and chemical parameters were recorded by taking water sampling done after 0, 5,10 and 15 days of growth of these four aquatic weeds in the tub (Table2.2).

Table 2.1: Layout design of the experiment

\begin{tabular}{|l|l|l|l|l|}
\hline & $\begin{array}{l}\text { TAPE } \\
\text { WATE } \\
\text { R }\end{array}$ & $\begin{array}{l}\text { BEKA } \\
\text { R } \\
\text { BAND } \\
\text { H }\end{array}$ & $\begin{array}{l}\text { MINE } \\
\text { WATER } \\
\mathbf{1}\end{array}$ & $\begin{array}{l}\text { MINE } \\
\text { WATER } \\
\mathbf{2}\end{array}$ \\
\hline $\begin{array}{l}\text { WATER } \\
\text { HYACINT } \\
\text { H }\end{array}$ & TWWH & BBWH & $\begin{array}{l}\text { MW1W } \\
\text { H }\end{array}$ & $\begin{array}{l}\text { MW2W } \\
\text { H }\end{array}$ \\
\hline $\begin{array}{l}\text { VETIVER } \\
\text { GRASS }\end{array}$ & TWVG & BBVG & MW1VG & MW2VG \\
\hline $\begin{array}{l}\text { HYDRILL } \\
\text { A }\end{array}$ & TWH & BBH & MW1H & MW2H \\
\hline ALGAE & TWA & BBA & MW1A & MW2A \\
\hline
\end{tabular}

Table.2.2: Layout of time for recording data

\begin{tabular}{|l|l|}
\hline O day & D1 \\
\hline After 5 days & D2 \\
\hline After 10 days & D3 \\
\hline After 15 days & D4 \\
\hline
\end{tabular}

All the chemical parameters were studied through standard methodology recommended by ISO9001:2009.

\section{FINDINGS \& DISCUSSION}

\section{$3.1 \mathrm{pH}$}

In the four different type of water taken as MW1, MW2, BB and TW treated with water hyacinth found increases in $\mathrm{pH}$ by $3.5,2.8,2.8$ and $0.7 \%$ increment in between $0-5$ days and $0,2.8,4.2$ and $5.7 \%$ increment in between 5-10 days and finally found 2.8, 2.1, 4.2 and $0 \%$ increment in between 1015 days intervals.

Whereas, when it is treated with vetiver grass it found increases in $\mathrm{pH}$ by $-2.1,2.8,2.1$ and $3.5 \%$ increment in between $0-5$ days and $0.7,0,0$ and $3.5 \%$ increment in between 5-10 days and 4.2, 2.1, 3.5 and $2.8 \%$ increment in between 10-15 days intervals. 


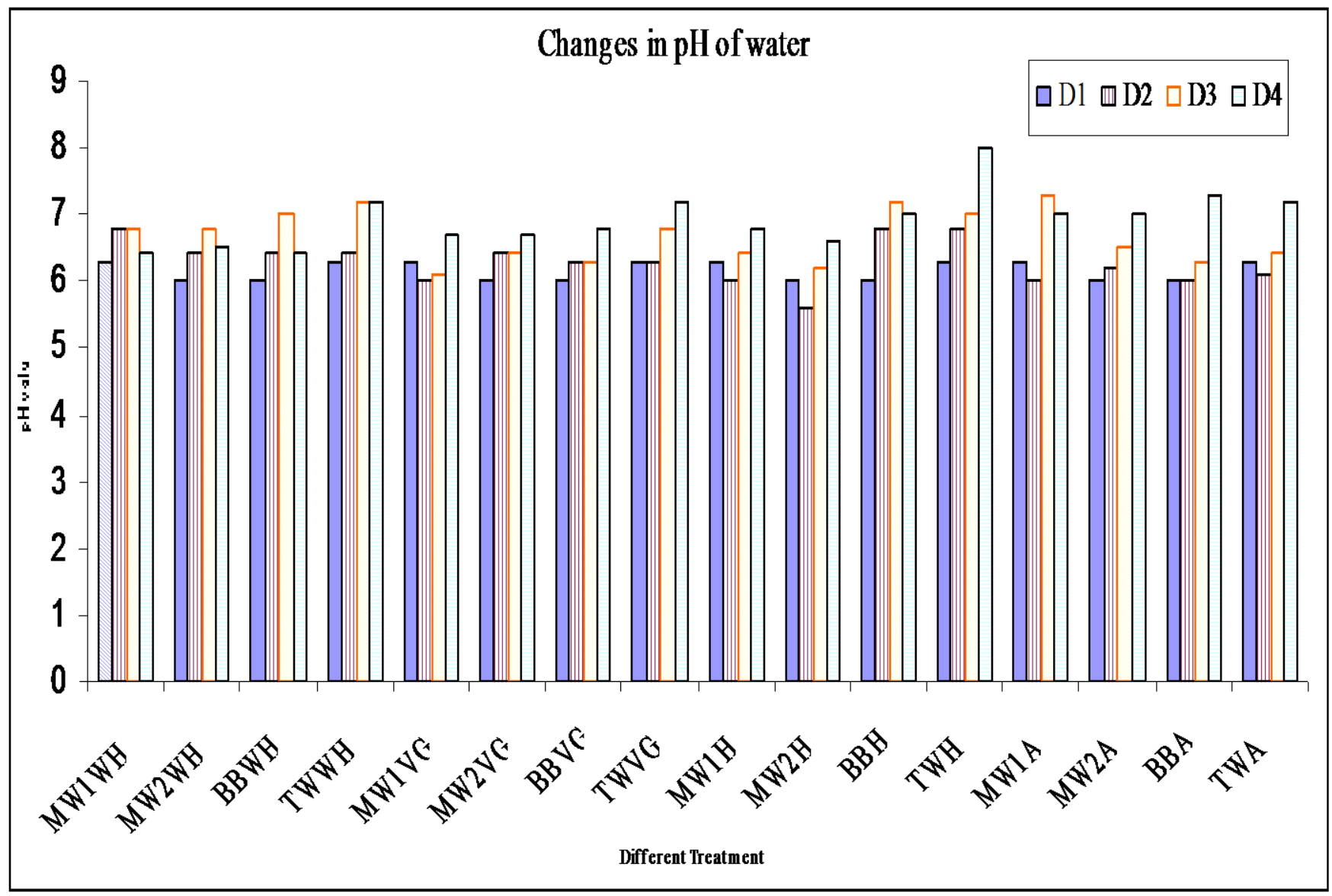

Fig.3.1: $\mathrm{pH}$ of the water samples

Wherein, treated with hydrilla found increases in $\mathrm{pH}$ by $-2.1,-2.8,5.7$ and $3.5 \%$ increment in between $0-5$ days and $2.8,4.2,2.8$ and $1.4 \%$ increment in between 5-10 days and 2.8, 2.8, 1.4 and $-7.1 \%$ increment in between 10-15 days interval.

Further, treated with algae found increases in $\mathrm{pH}$ by $-2.1,1.4,0$ and $-1.4 \%$ increment in between $0-5$ days and $9.2,2.1,2.1$ and $2.1 \%$ increment in between 5-10 days and 2.1, 3.5, 7.1 and 5.7\% increment in between 10-15 days interval. Mine wastewater is always acidic in nature increment is positive point and reduction results further acidic in nature. (-) increment means reduction in values.

Kumar et. al, (2014) reported maximum of $4 \%$ reduction in $\mathrm{pH}$ in mine wastewater treated with algae after 5 days duration. Manoharan and Subramaniyam (1993) agreed with above finding. But in the experiment within $10^{\text {th }}$ days to $15^{\text {th }}$ days of water treatment through algae and water hyacinth increases the $\mathrm{pH}$ instead of reduction. Wolvertonet. al, (1979), reported a decreases in $\mathrm{pH}$ in textile mill effluents with water hyacinth treatment. Moreover, Gamage and Yapa, (2001), reported the same reduction in $\mathrm{pH}$.

\subsection{NIitrate}

In the four different type of water taken as MW1, MW2, BB and TW treated with algae found reduction in nitrate by $0,77.77$, 77.77 and $0 \%$ in between $0-5$ days and $44.44,-48.89,-22.22$ and $100 \%$ in between $5-10$ days with $-66,-28,-55$ and $0 \%$ change in between 10-15 days interval. 


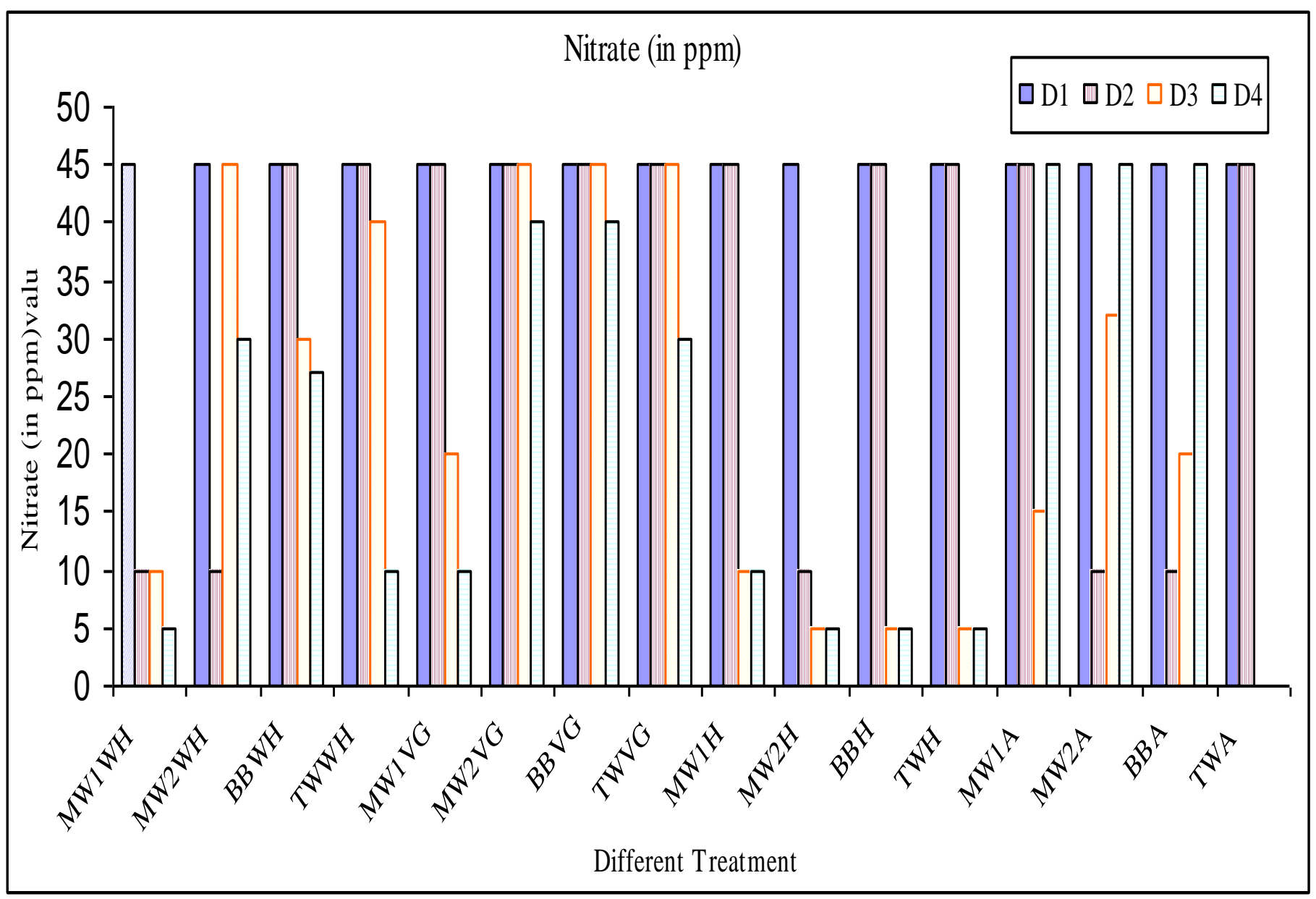

Fig.3.2: Nitrate in the water samples

In the four different type of water taken as MW1, MW2, BB and TW treated with hydrilla found reduction in nitrate by $0,77.77,0$ and $0 \%$ in between $0-5$ days and 77, 11, 88 and 88\% in between 5-10 days and 77, 88, 88 and 88.89\% in between 10-15 days interval.

In the four different type of water taken as MW1, MW2, BB and TW treated with vetiver grass found reduction in nitrate by 0 , 0 , 0 and $0 \%$ in between $0-5$ days and $11.11,11.11,33.33$ and $0 \%$ change in between $5-10$ days and $77,11,11$ and $33.33 \%$ reduction respectively within $10-15$ days interval.

In the four different type of water taken as MW1, MW2, BB and TW treated with water hyacinth found reduction in nitrate by 77, 77,0 and $0 \%$ in between $0-5$ days and $0,-77,33$ and $11 \%$ within $5-10$ days and finally $88,33,51$ and $77 \%$ in nitrate concentration within 10-15 days of interval.

These result corroborat with finding of Kshirsagar, (2013), and Rao et. al., (2011), who reported 78\% and 70\% reduction in nitrate nitrogen using algae in wastewater treatment. Tartte, et. al., (2010), observed effective removal of nitrogenous contaminant of waste water using Anabena and Nostoc algal species. Similarly recorded by the finding of Sengar et. al., (2011) who supporting the above trend and noted $91 \%$ reduction in nitrate using mixed algal population. The uptake and utilization of nitrate by algae species for their growth may be the reason for reduction in nitrate (Fig. 5.4 to 5.6). Whereas, Wooten and Dodd (1976) reported $100 \%$ removal of nitrate in water hyacinth system. Whereas, Sinclair and Forbes, 1980 reported 52.6\% and Cornwell, et. al., (1977) reported $8.4 \%$ of removal of Nitrate from wastewater containing water hyacinth.

\subsection{Iron}

In the four different type of water taken as MW1, MW2, BB and TW treated with water hyacinth found reduction in iron by 20 , 40, 40 and 40\% within 0-5 days and 20, 20, 40 and 40\% reduction in between 5-10 days with a final reduction of iron 40, 20, 40 and $40 \%$ in between $10-15$ days interval. 


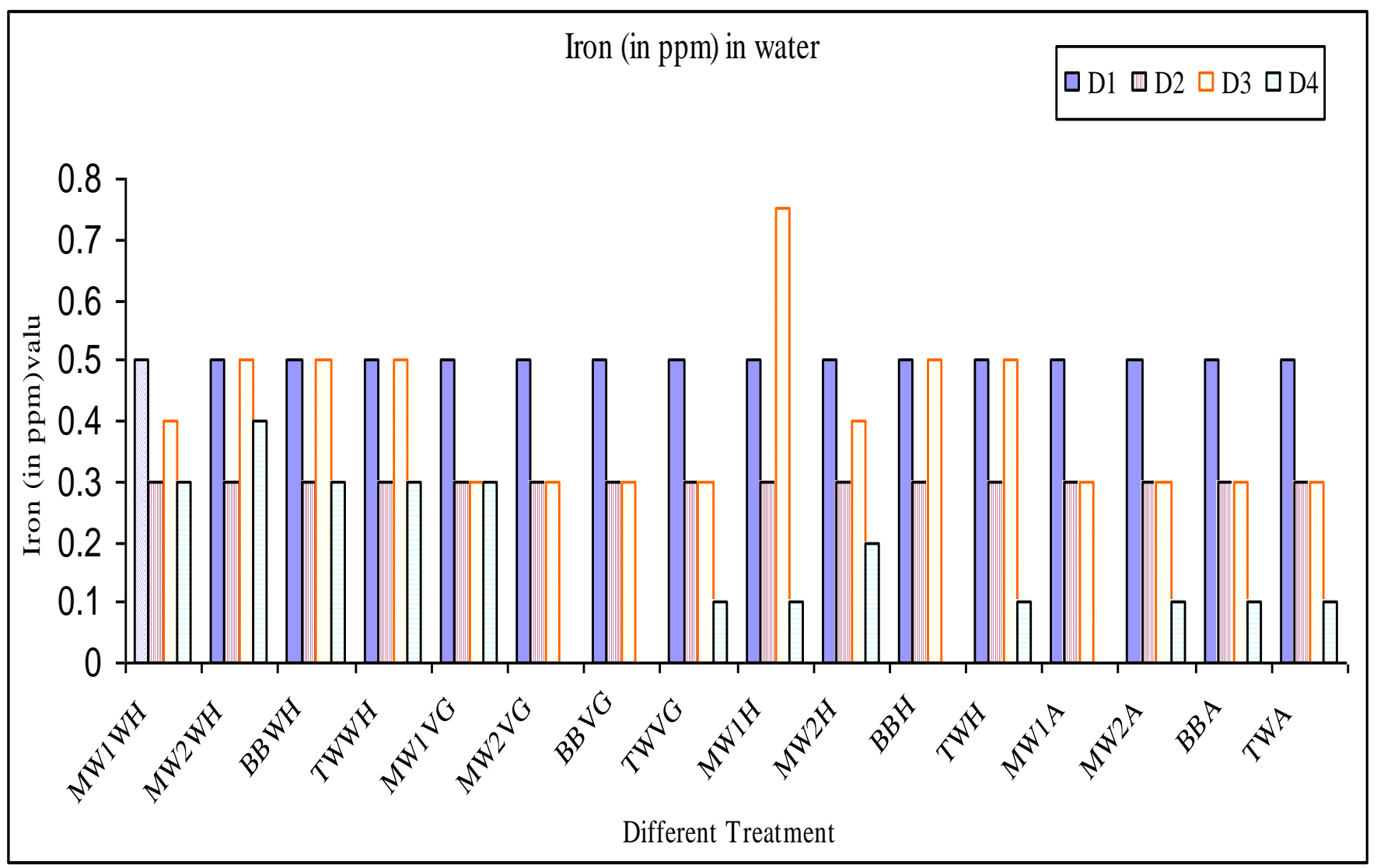

Fig.3.3: Iron in the water samples

In the four different type of water taken as MW1, MW2, BB and TW treated with vetiver grass found reduction in iron by $40 \%$ in all sample in between 0-5 days and 0,60,60 and 40\% reduction in between 5-10 days and finally reduction in concentration of iron by $40,100,100$ and $80 \%$ in between $10-15$ days.

In the four different type of water taken as MW1, MW2, BB and TW treated with hydrilla found reduction in iron by $90,20,40$ and $40 \%$ in between 0-5 days and 130, 40, 100 and 80\% reduction in between 5-10 days and finally change in concentration of iron by $80,60,100$ and $80 \%$ in the interval of $10-15$ days.

In the four different type of water taken as MW1, MW2, BB and TW treated with algae found reduction in iron by $40 \%$ in all sample in between 0-5 days and further 60, 40, 40 and 40\% reduction within 5-10 days and finally concentration of iron by 100, 80,80 and $80 \%$ after $10-15$ days interval.

Water hyacinth have high removal rate for Fe reported by Piyush Gupta et. al.,(2012). Mishra et. al., (2008), used water hyacinth for coal mining effluents for the removal of heavy metal and observed $70.5 \pm 4.4$ Fe was removed. Kumar et al (2014) reported reduction of $99 \%$ Fe in 5 mine water treated with algae after 5 days. The drastic change metals concentration in wastewater firstly observed by Oswald and Gootas, (1957).

\subsection{Sulphate}

In the four different type of water taken as MW1, MW2, BB and TW treated with water hyacinth found reduction in sulphate concentration by $25,27.5,24.3$ and $25 \%$ within $0-5$ days and by $25,25,24.39$ and $25 \%$ in between $5-10$ days with final reduction by $50,62,63$ and $50 \%$ sulphate within $10-15$ days interval respectively.

In the four different type of water taken as MW1, MW2, BB and TW treated with vetiver grass found reduction in sulphate concentration by $25,25,33$ and $25 \%$ in between $0-5$ days and $25,37,22$ and $37 \%$ reduction in between 5-10 days and finally was $50,62,66$ and $62.50 \%$ reduction in sulphate in between $10-15$ days interval. 


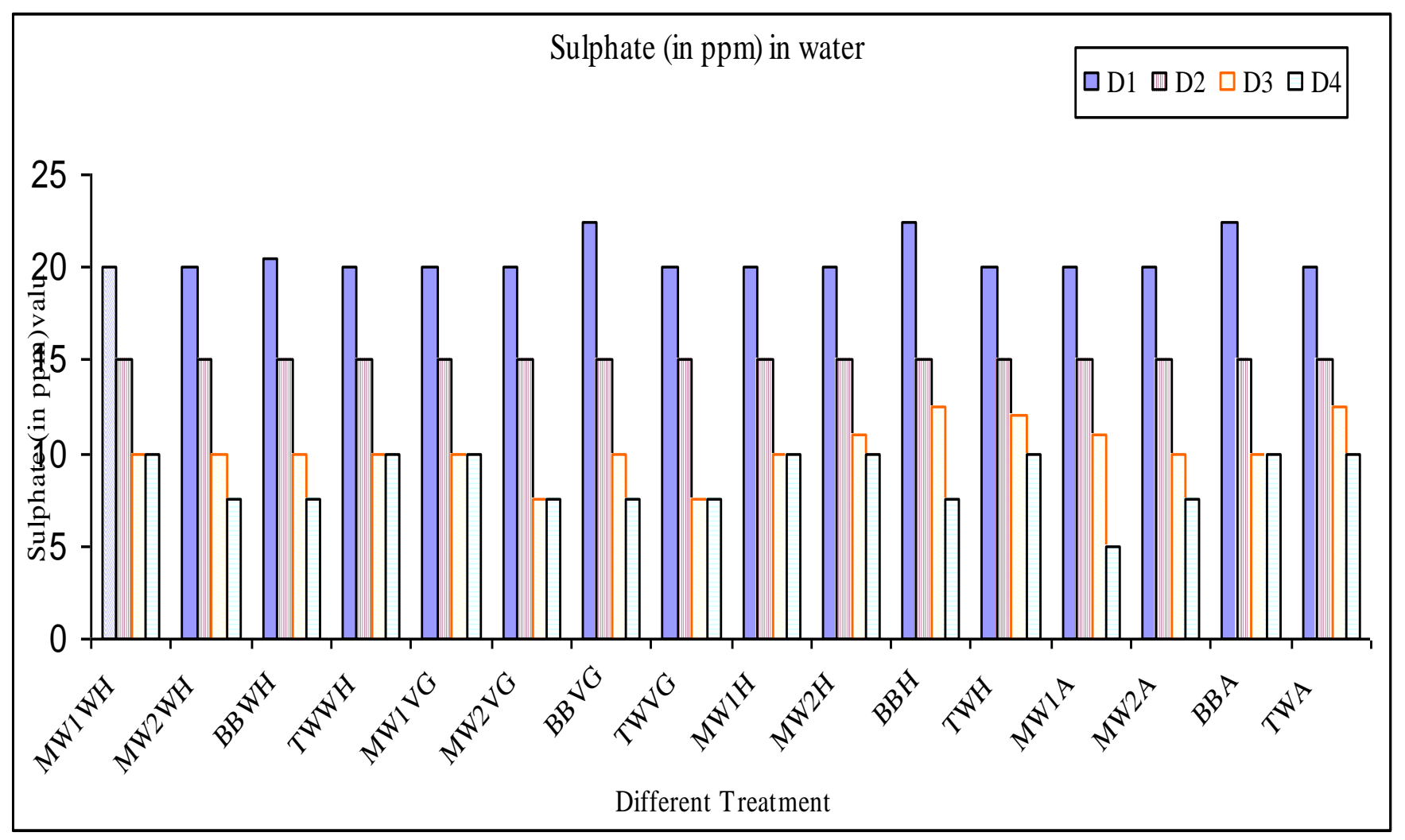

Fig.3.4: Sulphate in the water samples

In the four different type of water taken as MW1, MW2, BB and TW treated with hydrilla found reduction in sulphate concentration by $25,25,33$ and $25 \%$ and $25,20,11$ and $15 \%$ reduction in between 5-10 days with finally sulphate reduction by $50,50,66$ and $50 \%$ in between 10-15 days intervals.

In the four different type of water taken as MW1, MW2, BB and TW treated with algae found reduction in sulphate concentration by $25,25,33$ and $25 \%$ within $0-5$ days and by $20,25,22$ and $12.5 \%$ reduction in between 5-10 days finally $75,62,55$ and $50 \%$ reduction in between 10-15 days interval.

These results are in agreement with studies of Chandra et al., (2004) who reported more than $99 \%$ reduction in SO4-2 of tannery effluent with Nostoc.

Same trend was recorded by Ahmad et al., (2013) who also reported considerable reduction in SO4-2 using Chlorella and mixed algal culture. Elumalai et al., (2013) reported removal of very high amount of SO4-2 using consortium of algae as compare to single culture of Chlorella and Scynedesmus. Kumar and Chopra, (2012) recorded very high reduction in SO4-2 in municipal wastewater by using microbiological technology. In present study the SO4-2 removal capacity of both the algae was at par indicating equal efficiency for eliminating of SO4-2 from wastewater which may be contributed to its high uptake from polluted water for growth of algal species.

\section{CONCLUSION}

Bio-remediation of nitrate, sulphate, iron and lowering $\mathrm{pH}$ through four aquatic floating plants treated with two mine, one municipal waste and tap water in district Dhanbad shown result by significant reduction in the above nutrients in concentration with due course of time. Further, this technique can be substantially checked with its economic value as a whole process. This technique is sustainable approach in the area of zero waste management.

\section{ACKNOWLEDGEMENTS}

The authors are thankful to Director, CSIR-CIMFR, Barwa Road, Dhanbad-826015, Jharkhand for rendering all the required facilities for conducting the laboratory experiment during project training work and given permission for the publication of this article in the Journal.

\section{REFERENCES}

[1] Ahmad F, Khan AU and Yasar A. (2013). "Comparative phycoremediation of sewage water by various species of algae", Proceeding of Pakistan Academy of Sciences 50, 131-139.

[2] Araki H, Inoue $\mathrm{M}$ and Katoh T, (2003) "Total synthesis and absolute configuration of otteliones A and $\mathrm{B}$, novel and potent antitumor agents from a freshwater", Org Lett, 2003, 5(21), 3903-3906.

[3] Archibald, R.E.M, (1972), "Diversity in some South Africation diatom associations and its relation to water quality.” Water Research ,pp 1229-1238. 
[4] Awuah, E., Oppong-Peprah, M., Lubberding, H.J. and Gijzen, H.J., (2004), 'Comparative performance studies of water lettuce, duckweed and algal-based stabilization ponds using low-strength sewage", J. Toxicol. Environ. Health-Part A., 67(20-22), 17271739.

[5] B.C. Wolverton and R.C. McDonald (1981). "Energy from vascular plant wastewater treatment systems - Eichhorniacrassipes, Spirodelalemna, Hydrocotyleranunculoides, Puerarialobata" , Biomass harvested for fuel production. 35(2): pp224-232.

[6] Borges AKP, Tauk-Tornisielo SM, Domingos RN, Angelis DF. (2008). "Performance of the constructed wetland system for the treatment of water from the Corumbatai river". Braz. Arch. Biol. Technol. 51(6): 1279-1286.

[7] Braarud, T., (1945), “A phytoplankton survey of the polluted waters of Inner Oslo Fjord. Hvalraadets Skrifter", Scientific Results of Marine Biological Research 1945. No.28: 1-1

[8] Butcher, R.W, (1949), "Pollution and re-purification as indicated by the algae." Fourth Internat. Congress for Microbiology.,pp 149-150.

[9] Chandra R, Pandey PK, Srivastava A. (20040. "Comparative toxicological evaluation of untreated and treated tannery effluent with Nostoc muscorum L. (algal assay) and microtox bioassay". Environmental Monitoring and Assessment 95, 287294.

http://dx.doi.org/10.1023/B:EMAS.0000029909.879 77.a5.

[10] Chao, K. P., C. S. Chen, et al. (2005). "Aquacultural characteristics of Rhizocloniumriparium and an evaluation of its biomass growth potential." Journal of Applied Phycology 17(1): 67-73.

[11] Chao, K. P., Y. C. Su, et al. (1999). "Chemical composition and potential for utilization of the marine alga Rhizoclonium sp." Journal of Applied Phycology 11(6): 525- 533.

[12] Chao, K. P., Y. C. Su, et al. (2000). "Feasibility of utilizing Rhizoclonium in pulping and papermaking." Journal of Applied Phycology 12(1): 53-62.

[13] Cornwell, D.A., Zoltex, J., Patrinely, C.D., Furman, T.D. and Kin, J.I. (1977) "Nutrient Removal by Water Hyacinth", Journal of the Water Pollution Control Federation, Vol. 49, pp.57-65.

[14] Dhir B, Sharmila P, Saradhi PP (2008) Photosynthetic performance of Salvinianatans exposed to chromium and zinc rich wastewater. Braz. J. Plant. Physiol. Vol, 20,:pp 61-70.

[15] Dr Konstantin Bloch . Wastewater treatment using Algae in a Photobioreactor, 2001

[16] Droste, R.L. Theory and Practice of water and wastewater treatment, (1997) John Wiley and Sons.

[17] Elumalai S, Saravanan GK, Ramganesh S, Sakhtival R, Prakasam V. 2013. Phycoremediation of textile dye industrial effluent from tirupur district, Tamil
Nadu, India. International Journal of Science Innovations and Discoveries 3, 31-37.

[18] Filip, D.S., Peters, T., Adams, V.D. and Middlebrooks, E.J., (1979), "Residual heavy metal removal by an algae-intermittent sand filtration system., Water Res., vol, 13, pp 305-313.

[19] Fritioff A and Greger. M, (2006) "Uptake and distribution of $\mathrm{Zn}, \mathrm{Cu}, \mathrm{Cd}$, and $\mathrm{Pb}$ in an aquatic plant Potamogetonnatans". Chemosphere 63:220227.

[20] G.A. Alade, S.O. Ojoawo," Purification of domestic sewage by water-hyacinth (EichhorniaCrassipes", International Journal of Environmental Technology and Management 2009 - Vol. 10, No.3/4 pp. $286-$ 294

[21] GhanshyaPaswan and Kumar Nikhil. (2014) Biopurifiation of wastewater through algae. Internationl journal of engineering technical research. Vol, 2, pp 124-126.

[22] N. S. Gamage* And P. A. Yapa, 2001, Use of water hyacinth in treatment system for textile mill effluent- A case study", J Natn. Sci. Foundation, Sri Lanka, Vol.29(no.1\&2):pp.15-28

[23] Girija, N., Pillai, S.S and Koshy, M., 2011, Potential of vetiver for phytoremediation of waste in retting area., The Ecoscan, 1, 267-273

[24] Gopal, Brij (1987), "Water Hyacinth, Aquatic Plant Studies Series", ELSEVIER

[25] Grobbelaar, J.U., Soeder, D.J. and Stengel, E.,( 1990), "Modelling algal production in large outdoor cultures and waste treatment systems," pp 297-314.

[26] Hammouda, O., Gaber, A., and Abdel-Raouf, N. (1994) Microalgae and wastewater treatment. Ecotoxicol. Environ. Saf. 31: p. 205-210.

[27] Hassette, J.M., Jennett, J.C. and Smith, J.E., (1981), "Microplate technique for determining accumulation of metals by algae." Appli. Environ. Microbiol, vol, 41, pp 1097-106.

[28] K.R. Reddy and J.C. Tucker. (1983). Productivity and nutrient uptake of water hyacinth Eichhorniacrassipes. 1. Effect of nitrogenous source. Econ. Bot. 37(2):.pp-237-247.

[29] Kanabkaew, T. and Puetpaiboon, U. (2004), "Aquatic plants for domestic wastewater treatment: Lotus and Hydrilla (Hydrillaverticillata) systems Songklanakarin” J. Sci. Technol., 2004, 26(5) : 749756

[30] Kshirsagar. D Ayodhya (2013) "Remediation of domestic waste water by using alga and fungal mix culture, an experimental study". Bimonthly, Vol-4., pp-98.

[31] Kumar Gaurav, Kumar Nikhil \& Iqbal Ansari., (2014)., "Bioreclamation of Mine Waste Water through Algae:An Experimental Approach," IJETR, vol, 2, pp $265-269$.

[32] Kumar Nikhil, (2004), "Water Hyacinth: A Green tool for the sustainable development of coalfield", Ed. Tiwary R. K. "Biotechnological application in Environmental management”: pp 2-21. 
[33] Kumar V and Chopra AK (2012). "Monitoring of physiochemical and microbiological characteristics of municipal waste water at treatment plant Haridwar City, Uttarakhand". Journal of Envio. Sci.and tech 5, pp 109-118.

[34] Laliberte, G., Proulx, D., De Pauw, N. and De La Noüe, J.,(1994). 'Algal Technology in Wastewater Treatment". In: H. Kausch and W. Lampert (eds.), Advances in Limnology. E. Schweizerbart'sche Verlag sbuchhandlung, Stuttgart ; 283-382.

[35] Lovaie, A. and De La Noüe, J, (1985), "Hyperconcentrated cultures of Scenedesmusobliquus, A new approach for wastewater biological tertiary treatment", Water Res, vol, 19: pp 1437-42.

[36] Mackenthum, K.M., (1962), “A review of algae, lakeweeds and nutrients." J.WaterPollut.Control Fed., 34: pp 1077-85

[37] Mahmood, Q., Zheng, P., Islam, E., Hayat, Y., Hassan, M.J., Jilani, G. and Jin, R.C., (2005), "Lab scale studies on water hyacinth (Eichhorniacrassipes marts solms) for biotreatment of textile wastewater"., Caspian J. Env. Sci., 3(2), 83-88.

[38] Manoharan C and Subramanyan G, (1993). "Feasibility study by using cynobacteria of ocean effluent treatment". Vol-35, pp-88-96.

[39] Mata, T. M., A. A. Martins, et al. (2010). "Microalgae for biodiesel production and other applications: A review." Renewable \& Sustainable Energy Reviews vol, 14(1) pp 217-232.

[40] Mazen AMA, Maghraby OMO (1998) "Acumulation of cadimium, lead and strontium, and a role of calcium oxalate in water hyacinth tolerance". Biol. Plant. 40:411-417.

[41] Mishra, V.K., Upadhyay, A.R., Pandey, S.K. and Tripathi, B.D., (2008)b, "Heavy metal pollution induced due to coal mining effluent on surrounding aquatic ecosystem and its management through naturally occurring aquatic macrophytes"., Bioresource Technol., 99, 930-936.

[42] Mkandawire, M. and Dudel, E.G., (2007), "Are lemna spp. effective phytoremediation agents?’.,Boremediation, Biodiversity Bioavailability, 1(1), 56-71.

[43] Mulbry, W., S. Kondrad, et al. (2008). "Treatment of dairy and swine manure effluents using freshwater algae: fatty acid content and composition of algal biomass at different manure loading rates." Journal of Applied Phycology 20(6): 1079- 1085.

[44] Nakajima, A., Horikoshi, T., and Sakaguchi, T. (1981).Studies on the accumulation heavy metal elements in biological system XVII. Selective accumilation of heavy metal ions by Chlorella vulgaris." Eur. J. App. Microbiol. Biotechnol. Pp 76-83.

[45] Oswald W J, Gootas HB (1957), "photosynthesis in sewage treatmentrans" . American Soc. Civ. Eng. 122. Pp 73-105.

[46] Oswald, W.J. (1988), "Microalgae and Wastewater Treatment". In: Micro-algal Biotechnology, M.A.
Borowitzka and L.J. Borowitzka (eds). Cambridge University Press, New York (1988) pp. 357-94.

[47] Paiva LB, Oliveira JG, Azevedo RA, Ribeiro DR, Silva MG, Vitória AP (2009), "Ecophysiological responses of water hyacinth exposed to $\mathrm{Cr} 3+$ and Cr6+". Environ. Exp. Bot 65:403-409.

[48] Pal DK, Nimse SB, khatun $S$ and Padhiari A, (2005), "CNS activites of aqueous extract of Hydrilla plant", International conference of health science, Mysore, 2005, pp.60

[49] Pal DK, Padhihari AK, Otta M, Khatum S, Sangigrahi S and Mandal M (2004), "studies on antibactarial activity of Hydrilla," 16th annual conference of the PSI, Paschim Medinipur, 2004, pp. 77.

[50] Palmer, C.M. (1969), “A composite rating of algae tolerating organic pollution". J. Phycology. ; 5: 7882.

[51] Piyush Gupta1, Surendra Roy, Amit B. Mahindrakar, (2012), "Treatment of Water Using Water Hyacinth, Water Lettuce and Vetiver Grass A Review"., Resources and Environment, vol, 2(5)., pp 202-215.

[52] Prasad MNV (1995) "Cadmium toxicity and tolerance in vascular plants". Environ. Exp. Bot. 35:525-545.

[53] Ralph Ash and Paul Truong "The Use of Vetiver Grass for Sewerage Treatment" Utilities Engineer, Esk Shire Council, Esk, Queensland, Australia Veticon Consulting, Brisbane, Queensland, Australia (Paper for Sewage Management QEPA Conference, Cairns, Australia, April 5-7 2004)

[54] Rao, K.V., A.K. Khandekaran D. Vaidyanadham, (1973); "Uptake of fluoride by water hyacinth, Eichhorniacrassipes”. Ind.J.Exp.Biol., 11(1):68-5.

[55] Rao HP, Kumar RR, Raghavan BG, Subramanian VV and Sivasubramanian V (2011). "Application of phycoremediation technology in the treatment of wastewater from a leather-processing chemical manufacturing facility". Water. Soil, Air., 37(1): 714.

[56] Reddy, K.R. (1983) "Fate of Nitrogen and Phosphorus in a Wastewater Retention Reservoir Containing Aquatic Macrophytes". Journal of Environmental Quality;12(1): pp137-41.

[57] Roongtanakiat, N., Tangruangkiat, S. and Meesat, R., (2007), "Utilization of vetiver grass (Vetiveriazizanioides) for removal of heavy metals from industrial wastewaters"., ScienceAsia, 33, 397403

[58] Sakaguchi, T., Nakajima A. and Horikoshi, T, (1981), "Studies on the accumulation heavy metal elements in biological system XVIII". Accumilation of molybdenum by green microalgae". Eur. J. App. Microbiol. Biotechnol.,vol, 12, pp 84-89.

[59] Saravanan GK, Ramganesh s, Sakhtival R, Prakasham V. (2013), "Phyco remediation of textile dye industrial effluent for tirupur dist. Tamilnadu." International Journal of science \& Innovation and Discoveries.vol-3, pp 31-37. 
[60] Sarijeva G, Knapp M, Lichtenthaler HK (2007) "Differences in photosynthetic activity, chlorophyll and carotenoid levels, and in cholorophyll fluorescence parameters in green sun and shade leaves of Ginkgo and Fagus". J. Plant Physiol. 164:950-955.

[61] Sengar RMS, Singh KK, Singh S. (2011). "Application of phycoremediation technology in the treatment of sewage water to reduce pollution load". Indian Journal of Scientific Research 2, 33-39

[62] Sinclair, L.R., and R.B. Forbes. (1980), "Nutrient removal from drainage water with systems containing aquatic macrophytes.", Trans. ASAE 23:1184-1194.

[63] Skinner K, Wright N, Porter-Goff E (2007) "Mercury uptake and accumulation by four species of aquatic plants". Environ. Pollut. 145:234-237

[64] Soeder, C.J. (1981) "Productivity of microalgal systems. In Wastewater for aquaculture. University of the OFS", Bloemfontein:University of the OFS Publication, Series C, No. 3.

[65] Tartte V, Kalla CM, Murthy-Sistla DS, Fareeda G. (2010). "Comparative studies on growth and remediation of wastewater by two cyanobacterial biofertilizers". Agriculture Conspectus Scientifics 75, 99-103.

[66] Ting, Y.P., Lawson, E. and Prince, I.G, (1989), "Uptake of cadmium and zinc by alga Chlorella vulgaris": Part I. İndividual ion species. Biotechnol. Bioeng.,vol, 34, pp 990-99.

[67] Tredici, M. R. (2010). "Photobiology of microalgae mass cultures: understanding the tools for the next green revolution". Future Science.

[68] Tukendorf A (1993) "The response of spinach plants to excess of copper and cadmium". Photosynthetica 28:573-575.

[69] Vásquez, J. (2008). "Production, use and fate of Chilean brown seaweeds: re-sources for a sustainable fishery." Journal of Applied Phycology 20(5): 457-467.

[70] Vesk PA, Nockolds CE, Allaway WG (1999) "Metal localization in water hyacinth root from an urban rainy land'. Plant Cell Environ. 22:149-158.

[71] Vesk PA, Nockolds CE, Allaway WG (1999) "Metal localization in water hyacinth root from an urban rainy land". Plant Cell Environ. 22:149-158.

[72] Wolverton, B. C., and R. C. McDonald. (1979). "Water hyacinth (Eichhorniacrassipes) productivity and harvesting studies". Econ. Bot. 33: 1-10

[73] Wooten, J.W., Dodd, J.D., (1976). "Growth of water hyacinths in treated sewage effluent". Econ. Bot. vol, 30, pp 29-39.

\section{BIOGRAPHIES}

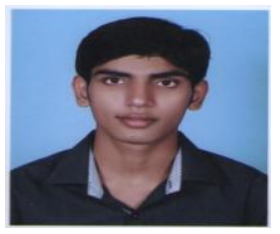

Pawan Kumar Gupta, IIIrd year student of B.E Biotechnology, R.V Collage of Engineering. Bangalore, Karnataka, done his project work at EMG, CSIR-CIMFR, Dhanbad, Jharkhand, India in the year 2014 and publishing his experimental finding.

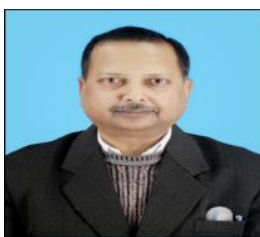

Dr. Kumar Nikhil, Ph.D in Env.Sc. \& Engg., Principal Scientist at Environmental Management Group, CSIR- Central Institute of Mining and Fuel Research (CIMFR), Barwa Road, Dhanbad - 826 015, Jharkhand, India has gained more than 30 years of research experience involved in more than 60 projects in different capacity. More than 135 scientific publications on his name. Guided more than 60 students of B,Sc, M.Sc, B.Tech \& M.Tech, $\mathrm{Ph} . \mathrm{D}$ students in their project and research works.

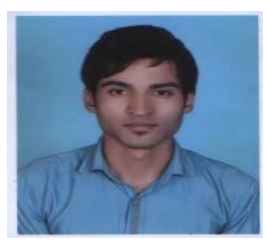

Kumar Mayank, IIIrd year student of B.E Biotechnology, R.V Collage of Engineering. Bangalore, Karnataka, given significant contribution in this paper by using mathematical tool and graphics for understanding clearly the bio-purification mechanism with different magnitude against time. 